Article

\title{
Influence of Soil Moisture Status on Soil Cadmium Phytoavailability and Accumulation in Plantain (Plantago lanceolata)
}

\author{
Aaron Stafford *, Paramsothy Jeyakumar ${ }^{(0)}$, Michael Hedley and Christopher Anderson \\ Institute of Agriculture \& Environment, Massey University Manawatu, Private Bag 11 222, \\ Palmerston North 4442, New Zealand; j.jeyakumar@massey.ac.nz (P.J.); M.Hedley@massey.ac.nz (M.H.); \\ c.w.n.anderson@massey.ac.nz (C.A.) \\ * Correspondence: Aaron.Stafford@ballance.co.nz; Tel.: +64-27-492-4274
}

Received: 29 November 2017; Accepted: 7 February 2018; Published: 12 February 2018

\begin{abstract}
The effect of fluctuating soil moisture cycles on soil cadmium (Cd) phytoavailability was investigated in a pot trial with two contrasting soils (Kereone (Allophanic), total Cd $0.79 \mathrm{mg} \mathrm{kg}^{-1}$; and Topehaehae (Gley), total Cd $0.61 \mathrm{mg} \mathrm{kg}^{-1}$ ) that were either sown with plantain (Plantago lanceolata) or left unseeded. Varying soil moisture contents were established using contrasting irrigation regimes: "flooded" (3 days flooded and then 11 days drained); or "non-flooded" (irrigation to 70\% of potted field capacity every 7 days). Overall, there was no significant difference in mean $0.05 \mathrm{M} \mathrm{CaCl}_{2}$ soil extractable $\mathrm{Cd}$ concentrations or plant tissue $\mathrm{Cd}$ concentrations between flooded and non-flooded irrigation. However, there was a consistent trend for an increase in soil extractable $\mathrm{Cd}$ concentrations following irrigation, regardless of the irrigation regime. Mean soil extractable $\mathrm{Cd}$ and plant tissue Cd concentrations were significantly greater (approximately $325 \%$ and $183 \%$, respectively) for the Topehaehae soil than the Kereone soil, despite the lower soil total Cd concentration of the Topehaehae soil. These results indicate that $\mathrm{Cd}$ solubility is sensitive to increases in soil moisture following periods of soil drainage, but insensitive to short-term periods of soil saturation. Plant tissue Cd concentrations in Cd-sensitive forage crops such as plantain are likely to be greater following large rainfall events over summer and autumn. This has the potential to increase animal dietary $\mathrm{Cd}$ exposure and rate of liver/kidney Cd accumulation.
\end{abstract}

Keywords: Cadmium; redox; phytoavailability; accumulation; plantain

\section{Introduction}

Cadmium $(\mathrm{Cd})$ is a non-essential element that is readily taken up by plants. Below phytotoxic concentrations, plants have little ability to regulate $\mathrm{Cd}$ uptake and accumulation [1]. Because of this, plant tissue $\mathrm{Cd}$ concentrations tend to increase with increasing soil Cd phytoavailability [1-3].

Many soil factors are known to influence soil $\mathrm{Cd}$ phytoavailability. These include total soil $\mathrm{Cd}$ concentration, $\mathrm{pH}$, organic matter content, mineralogy (i.e., clay types and abundance), the concentration of other anions and cations in soil solution, and soil redox potential [4-9]. Of these factors, soil $\mathrm{pH}$ is thought to be the most dominant factor controlling soil Cd phytoavailability, largely due to its overriding influence on the surface charge of variable charge clays and organic matter that dictates the soil's net negative charge and therefore $\mathrm{Cd}^{2+}$ sorption potential $[4,5,8,10-13]$.

Many authors have shown that moisture-driven changes in soil redox potential can also have a large influence on metal solubility [14-18]. Most research related to soil moisture-mediated changes in $\mathrm{Cd}$ phytoavailability has focused on prolonged periods of soil saturation (e.g., cultivation of rice), where the development of strongly-reducing soil conditions leads to a decrease in $\mathrm{Cd}$ solubility through the formation of insoluble Cd-sulphide complexes [19-21]. However, prolonged 
soil saturation is atypical for the majority of agricultural soil and crop management scenarios. For example, agricultural/horticultural production systems in New Zealand are based on either naturally well-drained soils or soils modified with artificial-drainage systems to control soil moisture within a desired range [22,23]. As a consequence, these soils are subject to fluctuating soil moisture and only temporary periods (i.e., several days) of soil saturation that occur when rainfall (and/or irrigation) exceeds the rate of soil drainage.

Unlike under prolonged anaerobic conditions, little is currently known regarding the behaviour of $\mathrm{Cd}$ under fluctuating soil moisture conditions punctuated by only short periods of saturation. Numerous studies have reported increases in the solubility of other metals following soil saturation and the associated onset of weakly- to moderately-reducing soil conditions $[16,24,25]$. This phenomenon is related to reduction-oxidation processes that govern the dissolution and precipitation of manganese $(\mathrm{Mn})$ and iron $(\mathrm{Fe})$ hydrous oxides. Under well-drained aerobic soil conditions, relatively insoluble $\mathrm{Fe}^{3+}$ and $\mathrm{Mn}^{4+}$ hydrous oxides prevail [22,24], providing sorption surfaces for many metals, including $\mathrm{Cd}[4,26-28]$. However, under anaerobic soil conditions, $\mathrm{Mn}^{4+}$ and $\mathrm{Fe}^{3+}$ become reduced to their more soluble $\mathrm{Mn}^{2+}$ and $\mathrm{Fe}^{2+}$ oxidation states [22,24]. With the consequent dissolution of these $\mathrm{Mn}$ and $\mathrm{Fe}$ hydrous oxides, co-sorbed metal ions are released into soil solution, increasing metal phytoavailability. Notably, Ponnamperuma [29] reported that reducing conditions can be established very rapidly (within a few days), suggesting that even short periods of soil saturation can influence the solubility and phytoavailability of metals sorbed to Fe/Mn hydrous oxides. This observation is supported by the work of Bhatti et al. [30], who attributed an increase in plant tissue As concentration to the dissolution of Fe hydrous oxides for plants grown under a cyclical 3-day flooded/11-day drained irrigation regime, relative to plants grown under irrigated but non-saturated soil conditions.

Due to the affinity between $\mathrm{Cd}^{2+}$ and $\mathrm{Fe} / \mathrm{Mn}$ hydrous oxides, there is a possibility that $\mathrm{Cd}$ phytoavailability could also be influenced by short-term periods of soil saturation, similar to the effects on As described by Bhatti et al. [30]. This hypothesis facilitates the successful examination of soil extractable $\mathrm{Cd}$ concentration differences over time (in addition to differences in plant $\mathrm{Cd}$ accumulation), since these should directly relate to the contrasting soil hydrological conditions (and redox potentials) imposed. The research described in this paper was therefore undertaken to quantify the effect of fluctuating soil moisture content and short-term periods of soil saturation on soil Cd phytoavailability and plant tissue $\mathrm{Cd}$ accumulation. Improving our understanding of the impact of soil moisture fluctuations on soil $\mathrm{Cd}$ phytoavailability may provide greater insight into appropriate strategies to better manage $\mathrm{Cd}$ accumulation in agricultural plant species.

\section{Materials and Methods}

The research described in this paper was conducted as a pot-trial, under controlled conditions, over the period April-September 2015. Two irrigation/soil moisture regimes were overlain on two contrasting soils (Kereone fine sandy loam and Topehaehae sandy clay loam; Table 1), which were either sown in plantain (Plantago lanceolata, cultivar "Ceres Tonic") or left as an unplanted control. Five replicates of each treatment were used (i.e., 40 pots in total). Plantain was chosen as the $\mathrm{Cd}$ phytoavailability indicator species in this trial based on previous research [31], which recorded high tissue $\mathrm{Cd}$ concentrations in this cultivar. Although chicory was shown to accumulate even greater tissue Cd concentrations than plantain [31] "Ceres Tonic" plantain is known to have greater cool season growth rate [32] —an important factor given that this trial was carried out over winter. 
Table 1. Soil classification and chemical characteristics of the two soils used in this study.

\begin{tabular}{ccc}
\hline Soil Type & Kereone Fine Sandy Loam & Topehaehae Sandy Clay Loam \\
\hline New Zealand Soil Classification & Typic Orthic Allophanic & Typic Recent Gley \\
USDA Taxonony & Udand & Aquept \\
Total Cd $\left(\mathrm{mg} \mathrm{kg}^{-1} \mathrm{DW}\right)$ & 0.79 & 0.61 \\
Total P $\left(\mathrm{mg} \mathrm{kg}^{-1} \mathrm{DW}\right)$ & 1577 & 1132 \\
Total Mn $\left(\mathrm{mg} \mathrm{kg}^{-1} \mathrm{DW}\right)$ & 1840 & 710 \\
Total Fe (\%) & 2.1 & 2.4 \\
Total C $(\%)$ & 5.7 & 3.2 \\
pH & 6.3 & 5.6 \\
Cation Exchange Capacity (meq $\left.100 \mathrm{~g}^{-1}\right)$ & 26 & 17 \\
P retention $(\%)$ & 69 & 34 \\
\hline
\end{tabular}

The imposed irrigation strategies (based on the methodology of Bhatti et al. [30]) were (i) "non-flooded", where soil moisture was maintained at 70\% potted field capacity $\left(\mathrm{F}_{\mathrm{P}}\right)$ utilising a 7-day irrigation cycle; and (ii) "flooded", where soil moisture was maintained at $110 \% \mathrm{~F}_{\mathrm{C}}$ for 3 days, subsequent to which drainage was permitted, allowing aeration of the soil over the ensuing 11 days, before the 14-day irrigation cycle was repeated.

\subsection{Pot Design}

To facilitate the proposed irrigation/soil moisture strategies, square white plastic pots $(16.5 \times 16.5 \times 19 \mathrm{~cm})$ were prepared based on the methodology of Bhatti et al. [30]. Briefly, for flood-irrigated pots, a $7 \mathrm{~mm}$ diameter hole was drilled into the side of the pot approximately $2 \mathrm{~cm}$ above the base. Into this, a $30 \mathrm{~cm}$ length of rubber tube (external diameter $8 \mathrm{~mm}$ and internal diameter $4 \mathrm{~mm}$ ) was inserted such that $15 \mathrm{~cm}$ of tube extended across the internal width of the pot and $15 \mathrm{~cm}$ extended externally (Figure 1). To facilitate flooded soil conditions for 3 days, the external length of rubber tube was bent over itself and clamped to prevent drainage. During the subsequent 11-day drained period, the tube was unclamped to facilitate soil drainage and aeration. Pots used for non-flooded conditions had two $3 \mathrm{~mm}$ diameter holes drilled into the base of each side (i.e., eight holes per pot) to permit drainage and soil aeration.

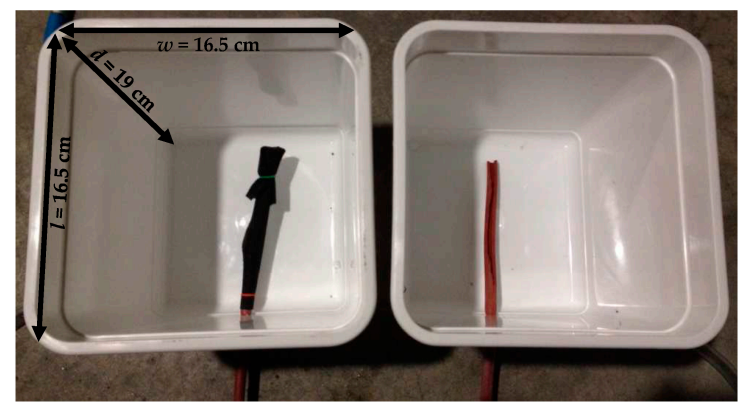

Figure 1. Design of pots (left, completed; right, partially complete showing the slit in the internal drainage tube) used for generating cyclical 3-day flooded, 11-day drained soil conditions.

A $20 \times 20 \mathrm{~cm}$ section of non-woven mulch mat was placed in the bottom of each non-flooded treatment pot. This water-permeable fabric extended approximately $2 \mathrm{~cm}$ up the internal wall of each pot, preventing soil loss through or blockage of the drainage holes located near the base of each side. For flooded pots, the section of rubber tube inside the pot had a narrow slit $(12 \mathrm{~cm} \times 0.3 \mathrm{~cm})$ cut out along the length of the tube. This internal rubber tube was then wrapped in mulch mat to prevent potential sediment blockage or loss. The bottom of all pots was then filled with $400 \mathrm{~g}$ of gravel $(6-13 \mathrm{~mm})$ to facilitate aeration and water movement around the drainage holes. All pots were then weighed to determine mass without soil added. 


\subsection{Soils}

Soils were collected from a commercial dairy farm in the Waikato region of New Zealand. Classification and chemical characteristics of the two soils is provided in Table 1. At the collection sites, the top $3 \mathrm{~cm}$ of soil was scraped off to remove the dense root mat of the ryegrass/white clover pasture sward. Soil from the A-horizon was then retrieved from 3 to $15 \mathrm{~cm}$ depth and sieved (field-moist) to $4 \mathrm{~mm}$. Each pot was packed with $3500 \mathrm{~g}$ of field moist soil, with a subsample of each soil taken for moisture content determination $\left(24 \mathrm{~h}\right.$ at $\left.105^{\circ} \mathrm{C}\right)$. The dry-soil gravimetric moisture content at potting was calculated at 0.42 and 0.43 for the Topehaehae and Kereone soils, respectively. On this basis, the oven-dry corrected mass of soil in each pot was 2464 and $2451 \mathrm{~g}$ for the Topehaehae and Kereone soils, respectively.

All pots were then watered until the soil was saturated. Once drainage had ceased, pots were re-weighed to determine the mass of water in each pot at $\mathrm{F}_{\mathrm{C}_{\mathrm{P}}}$. This mass of water at $\mathrm{F}_{\mathrm{P}}$ was then multiplied by either $70 \%$ or $110 \%$, and added to the combined mass of the oven-dry soil and pot apparatus, so as to determine the target total pot mass for each soil type by irrigation treatment.

\subsection{Experimental Layout and Management}

All pots were laid out in 4 rows of 10 pots in completely randomised design (CRD). The trial was carried out under a clear Perspex-roofed shelter at ambient air temperature (ranging from $0.1^{\circ} \mathrm{C}$ to $21.7^{\circ} \mathrm{C}$ ) in Tauranga, Bay of Plenty. Daily mean, minimum, and maximum air temperature data for Tauranga over the experimental period is shown in Figure 2. Throughout the duration of the trial, pots were rotated on a weekly basis to ensure there was no environmental bias for any replicate.

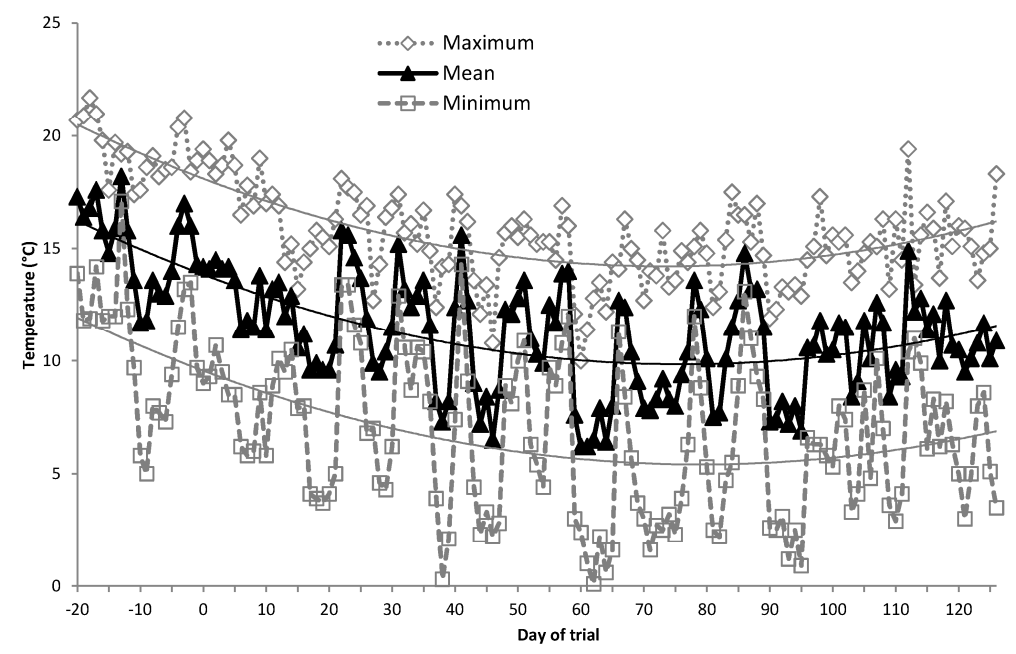

Figure 2. Daily mean, maximum, and minimum temperatures recorded at Tauranga airport (NIWA "CliFlo" climate station 1615) over the duration of the trial period.

Plantain seeds were sown in the appropriate pots on 20 April 2015 (day -20). Divergence in irrigation strategy occurred on 10 May 2015 (day 0), once seedlings had germinated, become well established, and had been thinned to one healthy plant per pot. The trial was completed on 13 September 2015 (day 126).

\subsection{Soil Sampling and Plant Harvest}

Immediately prior to the initiation of the different irrigation strategies (day 0), a single soil core (100 mm depth, $18 \mathrm{~mm}$ diameter) was extracted from each pot. Further soil samples were taken 3 days later, timed in alignment with the end of the 3-day "saturated" phase of the flooded treatments. Flooded treatments were allowed to drain over the subsequent 11 days, before this "pre-irrigation" and "+3 day" sampling strategy was repeated, coinciding with each 14-day flood irrigation cycle. In total, 
this fortnightly soil sampling cycle was repeated nine times (i.e., 18 paired samples). Soil removed at each sampling was backfilled with surplus soil from each soil type that had been sieved and kept in storage. Soil sampling sites were rotated clockwise around each pot, with the location of backfilled soil sampling sites marked with a toothpick.

Plantain was harvested from all pots when "grazing-maturity" was reached within the treatments exhibiting the greatest growth rates (non-flooded Kereone and Topehaehae treatments). This occurred on day 126. Plant tissue samples were harvested $20 \mathrm{~mm}$ above the soil surface, weighed, washed, and oven-dried $\left(60^{\circ} \mathrm{C}\right.$ for 3 days) for dry matter content (\% DM), dry matter yield $\left(\mathrm{g} \mathrm{DM} \mathrm{pot}^{-1}\right)$ and tissue $\mathrm{Cd}\left(\mathrm{mg} \mathrm{kg}^{-1} \mathrm{DM}\right)$ assessment.

\subsection{Chemical Analysis}

Following the procedure of Li et al. [33], $6 \mathrm{~g}$ of field moist soil was extracted in $30 \mathrm{~mL}$ of $0.05 \mathrm{M}$ $\mathrm{CaCl}_{2}$ with $24 \mathrm{~h}$ end-over-end shaking. The samples were then centrifuged at $11,953 \times g$ for $10 \mathrm{~min}$ before filtering (Whatman No. 42). Plant tissue samples were crushed and homogenised prior to analysis for Cd, following the methodology described by Jeyakumar et al. [34] for plant metal analysis. Briefly, $0.1 \mathrm{~g}$ of each sample was digested using $10 \mathrm{~mL}$ of $69 \% \mathrm{HNO}_{3}$. Cadmium in the soil extracts and plant tissue digests was assessed using a graphite furnace atomic absorption spectrophotometer (GFAAS; Perkin-Elmer AAnalyst 600, Waltham, MA, USA).

The $\mathrm{pH}$ of $0.05 \mathrm{M} \mathrm{CaCl}_{2}$ soil extracts was assessed for all samples at sampling days $0,28,84$, and 112. This was undertaken using a Eutech Instruments CyberScan $\mathrm{pH} 310$ fitted with an $\mathrm{Ag} / \mathrm{AgCl}$ oxidation reduction potential reference electrode.

For each treatment, the mean soil extractable $\mathrm{Cd}$ concentration was determined using replicate data across all sampling occasions. Treatment-mean soil extractable $\mathrm{Cd}$ concentrations were also independently assessed for samples collected at pre-irrigation and +3 day sampling timings. This also allowed the mean change in soil extractable $\mathrm{Cd}$ concentrations between pre-irrigation and +3 day samplings to be determined on a treatments basis, to test the hypothesis that this variance should be greater in flooded than non-flooded treatments.

\subsection{Quality Control}

All chemicals used in the experiments were of analytical grade. The GFAAS limit of detection for $\mathrm{Cd}$ in digest solution was $0.002 \mathrm{mg} \mathrm{L}^{-1}$. Analytical accuracy was assessed through parallel analysis of a certified standard reference material (NIST 1573a, tomato leaves). The analysed concentration differed by less than $5 \%$ of the certified value. GFAAS calibration rescale was performed every 30 samples.

\subsection{Statistical Analysis}

Statistical analysis was carried out using IBM SPSS Statistics for Windows, version 22 (IBM Corp., Armonk, NY, USA). Significant outliers were identified using Tukey's outlier filtering method [35]. Analysis of variance (ANOVA) was undertaken to assess differences in treatment means, and Tukey's honestly significant difference (HSD) was run as a post-hoc analysis to identify differences between individual treatment means.

\section{Results}

\subsection{Soil Extractable $C d$}

The mean soil extractable $\mathrm{Cd}$ concentration across the duration of the trial was significantly $(p<0.001)$ different between the two soils (Table 2$)$, with soil extractable Cd concentrations being approximately four-times greater in the Topehaehae soil $\left(85 \mu \mathrm{g} \mathrm{kg}^{-1}\right)$ than the Kereone soil $\left(20 \mu \mathrm{g} \mathrm{kg}^{-1}\right)$. However, there was no significant effect $(p>0.05)$ of irrigation regime or of plant on extractable $\mathrm{Cd}$ concentration within the same soil. 
Table 2. Mean soil extractable Cd concentration ( $\mu \mathrm{g} \mathrm{kg} \mathrm{kg}^{-1}$ ) across the 18 paired sampling dates; (i) Overall mean; (ii) Mean of pre-irrigation samplings; and (iii) Mean of +3 day samplings; in addition to (iv) Mean plant tissue Cd concentration ( $\mathrm{mg} \mathrm{kg}^{-1} \mathrm{DM}$ ); (v) Plant yield (g DM pot ${ }^{-1}$ ); and (vi) Plant Cd uptake ( $\mu \mathrm{g}$ Cd pot ${ }^{-1}$ ). Within a row, treatment means with the same letter indicate that differences are not significant from one another $(p<0.05)$.

\begin{tabular}{|c|c|c|c|c|c|c|c|c|c|c|}
\hline \multirow{2}{*}{ Measure } & & \multicolumn{8}{|c|}{ Treatment } & \multirow{2}{*}{$p$-Value } \\
\hline & & KPN & KUN & KPF & KUF & TPN & TUN & TPF & TUF & \\
\hline \multirow{10}{*}{$\begin{array}{l}\text { Soil extractable Cd } \\
\left(\mu \mathrm{gg}^{-1}\right)\end{array}$} & (i) Overall mean & 20.9 (a) & 21.1 (a) & $20.0(a)$ & 18.5 (a) & $84.4(\mathrm{~b})$ & $89.3(b)$ & 88.9 (b) & $86.1(b)$ & $* * *$ \\
\hline & Std. Error & 0.7 & 0.7 & 0.8 & 0.8 & 3.4 & 3.4 & 3.5 & 3.4 & \\
\hline & $n$ & 88 & 87 & 88 & 84 & 86 & 88 & 87 & 84 & \\
\hline & (ii) Pre-irrigation mean & $19.3(\mathrm{a})$ & $19.4(\mathrm{a})$ & 17.9 (a) & 16.1 (a) & $83.0(b)$ & $87.6(b)$ & $85.4(b)$ & $81.4(b)$ & $* * *$ \\
\hline & Std. Error & 1.0 & 1.1 & 1.0 & 1.1 & 5.4 & 5.2 & 4.9 & 5.0 & \\
\hline & $n$ & 44 & 43 & 45 & 41 & 44 & 44 & 44 & 40 & \\
\hline & (iii) +3 day mean & $22.6(a)$ & 22.7 (a) & 22.1 (a) & 20.7 (a) & $86.0(\mathrm{~b})$ & $91.0(b)$ & $92.5(b)$ & $90.4(b)$ & $* * *$ \\
\hline & Std. Error & 1.0 & 0.9 & 1.2 & 1.1 & 4.1 & 4.3 & 4.9 & 4.6 & \\
\hline & $n$ & 44 & 44 & 43 & 43 & 42 & 44 & 43 & 44 & \\
\hline & $p$-value (pre-irrigation vs. +3 day) & * & * & ** & ** & n.s. & n.s. & n.s. & n.s. & \\
\hline \multirow{5}{*}{$\begin{array}{l}\text { (iv) Plant tissue Cd } \\
\left.\text { (mg kg }{ }^{-1} \mathrm{DM}\right)\end{array}$} & Mean & $0.208(\mathrm{a})$ & & $0.384(\mathrm{ab})$ & & $0.650(\mathrm{c})$ & & $0.604(\mathrm{bc})$ & & *** \\
\hline & Std. Error & 0.059 & & 0.077 & & 0.054 & & 0.068 & & \\
\hline & $n$ & 5 & & 5 & & 5 & & 5 & & \\
\hline & Main effect-Soil type & $* * *$ & & & & & & & & \\
\hline & Main effect-Irrigation regime & n.s. & & & & & & & & \\
\hline \multirow{4}{*}{$\begin{array}{l}\text { (v) Plant yield } \\
\text { (g DM pot }{ }^{-1} \text { ) }\end{array}$} & Mean & $5.40(\mathrm{c})$ & & $2.70(a b)$ & & $4.02(\mathrm{bc})$ & & $1.51(\mathrm{a})$ & & $* * *$ \\
\hline & Std. Error & 0.57 & & 0.29 & & 0.30 & & 0.16 & & \\
\hline & Main effect-Soil type & n.s. & & & & & & & & \\
\hline & Main effect-Irrigation regime & $* * *$ & & & & & & & & \\
\hline \multirow{4}{*}{$\begin{array}{l}\text { (vi) Plant Cd uptake } \\
\left(\mu \mathrm{g} \mathrm{Cd} \operatorname{pot}^{-1}\right)\end{array}$} & Mean & 1.001 (a) & & 1.020 (a) & & $2.602(b)$ & & 0.880 (a) & & $* * *$ \\
\hline & Std. Error & 0.224 & & 0.182 & & 0.280 & & 0.056 & & \\
\hline & Main effect-Soil type & * & & & & & & & & \\
\hline & Main effect-Irrigation regime & * & & & & & & & & \\
\hline
\end{tabular}

${ }^{*} p \leq 0.05,{ }^{* *} p \leq 0.01,{ }^{* * *} p \leq 0.001$, n.s. $=$ not significant. Treatment codes: $\mathrm{K}=$ Kereone, $\mathrm{T}=$ Topehaehae; $\mathrm{P}=$ Planted, $\mathrm{U}=\mathrm{Unplanted} ; \mathrm{N}=\mathrm{Non}-\mathrm{flooded}, \mathrm{F}=$ Flooded 
When samples were separated into those taken at pre-irrigation and at the +3 day timings (Table 2), there was a consistent trend whereby mean soil extractable $\mathrm{Cd}$ concentrations were greater for the +3 day samples relative to the pre-irrigation samples; however, these differences only reached significance $(p<0.05)$ for treatments within the Kereone soil. Within the Kereone soil, the difference in soil extractable $\mathrm{Cd}$ concentrations between pre-irrigation and +3 day sampling timings was of greater significance for flooded treatments $(p<0.01)$ than the non-flooded treatments.

\section{Soil Extractable Cd over Time}

Figure 3 presents a graphical comparison of the mean soil extractable $\mathrm{Cd}$ concentration at each sampling date for the flooded and non-flooded treatments of the Topehaehae planted, Topehaehae unplanted, Kereone planted, and Kereone unplanted treatments (Figure 3a-d, respectively). The trend for greater soil extractable $\mathrm{Cd}$ concentrations at +3 day samplings relative to the pre-irrigation samplings in both flooded and non-flooded treatments is illustrated in these graphs.

Within all treatments, there was a general increase in soil extractable $\mathrm{Cd}$ concentrations over the first 4- 6 weeks of the trial. This phase was then followed by a decrease in soil extractable $\mathrm{Cd}$ concentration, with the Topehaehae soil in particular showing an abrupt 50-60\% decrease over days 42-56 (Figure 3a,b). Although not as abrupt, a similar trend was seen for the Kereone soil (Figure 3c,d), where an approximate $60 \%$ decrease in soil extractable $\mathrm{Cd}$ concentration occurred over the latter half of the trial. This decline was not an effect of plant uptake, since soil extractable Cd concentrations in non-planted treatments showed the exact same patterns as the planted treatments throughout the duration of the trial. 

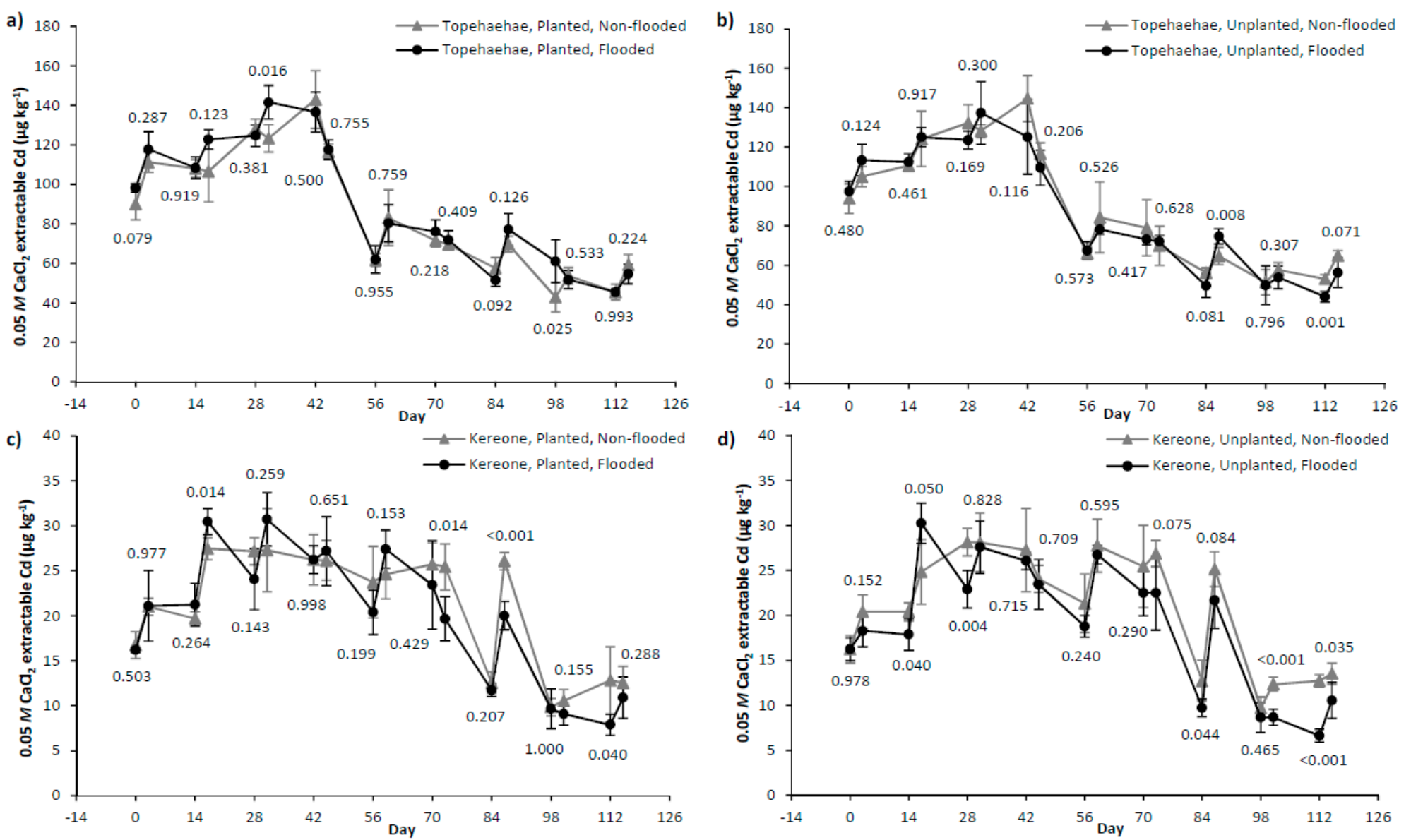

Figure 3. Mean soil extractable $\mathrm{Cd}$ concentrations $\left(\mu \mathrm{g} \mathrm{kg}^{-1}\right)$ at each sampling date under flooded and non-flooded conditions for (a) Topehaehae Planted; (b) Topehaehae Unplanted; (c) Kereone Planted; and (d) Kereone Unplanted treatments. ANOVA $p$-values are provided for comparison of means at each sampling date. Error bars represent the $95 \%$ confidence interval. 


\subsection{Soil Solution $p H$}

Periodic assessment of soil solution $\mathrm{pH}$ throughout the duration of the trial indicated that with the exception of the Kereone planted flooded treatment at day 28, there was no consistent significant $(p>0.05)$ effect of irrigation regime on solution $\mathrm{pH}$ (Table 3). Overall, there was a significant $(p<0.001)$ increase in soil solution $\mathrm{pH}$ throughout the course of the trial.

Table 3. $\mathrm{pH}$ of $0.05 \mathrm{M} \mathrm{CaCl}_{2}$ extracts assessed periodically throughout the trial. Means with the same letter indicate that differences from one another are not significant $(p<0.05)$. Lower-case letters represent comparisons between irrigation treatment means $(n=5)$ and upper-case letters represent comparisons between the overall mean $\mathrm{pH}$ at different time intervals $(n=20)$.

\begin{tabular}{|c|c|c|c|c|c|}
\hline \multirow{2}{*}{$\begin{array}{l}\text { Irrigation } \\
\text { Treatment }\end{array}$} & \multicolumn{4}{|c|}{ Day of Sampling } & \multirow{2}{*}{$p$-Value } \\
\hline & 0 & 28 & 84 & 112 & \\
\hline KPN & 4.04 & $4.09(\mathrm{ab})$ & 4.29 & 4.44 & \\
\hline $\mathrm{KPF}$ & 3.94 & $4.28(b)$ & 4.38 & 4.27 & \\
\hline TPN & 3.97 & $4.00(\mathrm{a})$ & 4.17 & 4.23 & \\
\hline TPF & 3.92 & $4.10(\mathrm{ab})$ & 4.13 & 4.12 & \\
\hline$p$-value & 0.150 & 0.042 & 0.294 & 0.144 & \\
\hline Sampling mean & $3.97(\mathrm{~A})$ & $4.11(\mathrm{AB})$ & $4.24(\mathrm{~B})$ & 4.27 (B) & $<0.001$ \\
\hline
\end{tabular}

\subsection{Plantain Tissue Cd Concentration, Yield, and Cd Uptake}

Significant $(p<0.001)$ differences in overall treatment mean plantain tissue Cd concentrations were apparent (Table 2), with mean tissue $\mathrm{Cd}$ concentrations decreasing in the order Topehaehae non-flooded $>$ Topehaehae flooded $>$ Kereone flooded $>$ Kereone non-flooded. However, the main effect was that of soil type $(p<0.001)$, with plant tissue Cd concentrations for the Topehaehae soil being approximately double those for the Kereone soil. In contrast, the main effect of irrigation regime on tissue $\mathrm{Cd}$ concentration was not significant $(p>0.05)$.

Dry matter yield of plantain was significantly $(p<0.001$; Table 2$)$ influenced by irrigation regime, however there was no relationship $(p>0.05)$ to soil type. Within the Kereone soil, there was an inverse relationship between plant yield and tissue $\mathrm{Cd}$ concentration. As a consequence, total $\mathrm{Cd}$ uptake was not significantly $(p>0.05)$ different for the flooded and non-flooded treatments. In contrast, in the Topehaehae soil, plant tissue Cd concentrations were not influenced $(p>0.05)$ by differences in plant yield between the two irrigation regimes. As a consequence, total $\mathrm{Cd}$ uptake was significantly $(p<0.05)$ greater in the higher-yielding non-flooded treatment.

\section{Discussion}

\subsection{Effect of Fluctuating Soil Moisture on Soil Cd Phytoavailability}

The results indicate that the solubility of soil $\mathrm{Cd}$ is sensitive to initial increases in soil moisture content following periods of soil drainage, but insensitive to short-term periods of soil saturation. This is shown by the consistent increases in soil extractable $\mathrm{Cd}$ concentrations measured at the +3 day sampling timing relative to pre-irrigation, regardless of irrigation strategy (Table 2 and Figure 3). In addition, there was a lack of difference in plant tissue $\mathrm{Cd}$ concentrations between flooded and non-flooded irrigation regimes in our trial (Table 2), providing further evidence that $\mathrm{Cd}$ phytoavailability is insensitive to short-term periods of soil saturation. This is an important finding, given that previous research $[16,21,24-26]$ has indicated that changes in soil redox potential can influence Cd solubility.

Although we did not directly assesses soil redox potential, it is known that soil redox potential can change within a few days of saturation [29]. As change in redox potential is expected to influence soil solution $\mathrm{pH}[29,36-39]$, the lack of difference in soil solution $\mathrm{pH}$ between irrigation regimes in our study (Table 3 ) suggests that either (i) both soils buffered potential $\mathrm{pH}$ changes brought about by 
differences in redox processes driven by the different irrigation regimes; or (ii) that the 3-day flooded period was insufficient for generating reducing soil conditions. Notably, Bhatti et al. [30] employed a very similar irrigation methodology to that used in our study, and reported significant increases in plant As concentration under flooded compared to non-flooded irrigation treatments, which they attributed to the dissolution of Fe hydrous oxides under the short-term flooded conditions. Although Bhatti et al. [30] did not directly measure soil redox potential, their results indicate that the solubility of As is much more sensitive than $\mathrm{Cd}$ to short periods of soil saturation.

Potentially, the lack of difference in Cd solubility between the two irrigation regimes in this study could also be related to soil $\mathrm{pH}$. It is known that the dissolution of Mn hydrous oxides can occur even under oxidising conditions when soil pH is mildly acidic [36]. Given that both the Topehaehae and Kereone soils had mildly acidic soil pH at the time of soil collection (pH 5.6 and 6.3, respectively; Table 1), it is possible that dissolution of $\mathrm{Mn}$ hydrous oxides (and concurrent release of $\mathrm{Cd}$ ) could have occurred with increased soil moisture, regardless of irrigation regime.

\subsection{Change in Soil Extractable $C d$ as a Function of Time}

This study is the first to evaluate changes in $\mathrm{Cd}$ solubility over time under contrasting wetting/drying soil moisture cycles. The study recorded an increase in soil extractable $\mathrm{Cd}$ concentration over the first 4-6 weeks of the trial, followed by a large (50-60\%) decrease thereafter, which was consistent for both irrigation regimes and soil types (Figure 3). Data presented in Figure 3 indicate that in the initial 4-6 weeks of the trial, the increase in soil extractable Cd concentrations that occurred between each pre-irrigation and +3 day sampling was not reversed (or completely reversed) over the subsequent drained phase, resulting in successively greater soil extractable $\mathrm{Cd}$ concentrations at each subsequent pre-irrigation sampling. With relatively dry soil conditions at the time of soil collection (gravimetric moisture content $\left(\theta_{\mathrm{m}}\right)$ for both soils of $\sim 0.42 \mathrm{~g} \mathrm{~g}^{-1}$, compared to $\theta_{\mathrm{m}}$ at $F_{\mathrm{C}_{\mathrm{P}}}$ of 0.64 and $0.73 \mathrm{~g} \mathrm{~g}^{-1}$ for the Topehaehae and Kereone soils, respectively), it is possible that the trend for increasing soil extractable Cd concentrations over the first 4-6 weeks of the trial was a consequence of the abrupt increase in soil moisture. This is consistent with previous research [40] that showed a large increase in soil solution $\mathrm{Cd}^{2+}$ and total $\mathrm{Cd}$ concentrations (approximately $100 \%$ and $50 \%$, respectively) in the first $48 \mathrm{~h}$ following rewetting of air-dried soil samples, which the authors attributed to the establishment of anaerobic soil microbial respiration processes. Furthermore, as soil organic matter is an important sink for Cd in New Zealand agricultural soils [41] it is also possible that mineralisation of soil organic matter following sieving/potting may have reduced the soils' Cd sorption potential, thereby increasing labile-Cd during the first 4-6 weeks of this study.

The consistent decline in soil extractable $\mathrm{Cd}$ concentrations that occurred beyond days 42-56 coincided with a small but significant $(p<0.001)$ increase in the $\mathrm{pH}$ of $0.05 \mathrm{M} \mathrm{CaCl}_{2}$ soil extracts that occurred relative to that measured at day 0 (Table 3). With an increase in $\mathrm{pH}$, specific sorption of $\mathrm{Cd}$ would be expected to increase with a corresponding decrease in Cd phytoavailability $[4,8,11,13]$. The increase in soil solution $\mathrm{pH}$ is therefore consistent with the decrease in soil extractable $\mathrm{Cd}$ concentrations measured mid-way through the trial. This does not contradict the increase in soil extractable $\mathrm{Cd}$ concentrations observed during the initial 4-6 weeks (Figure 3), since soil solution $\mathrm{pH}$ during this period did not change significantly $(p>0.05)$ (Table 3$)$.

Alternatively, the decline in soil extractable $\mathrm{Cd}$ concentrations mid-way through the trial may have been temperature-related. The decline aligned with the coldest period of winter, when overnight temperatures regularly approached $0{ }^{\circ} \mathrm{C}$ (Figure 2). With a decrease in temperature, a decrease in the decomposition rate of soil organic carbon is expected [42]. As a consequence of this decrease in energy availability, lower respiratory oxygen demand is likely to result in a decrease in microbially-induced reduction [43]. Hindersmann and Mansfeldt [24] reported an inverse relationship between temperature and the time taken to transition from oxidising to weakly reducing soil conditions, noting an increase from 10 to $160 \mathrm{~h}$ at temperatures of $15^{\circ} \mathrm{C}$ and $7{ }^{\circ} \mathrm{C}$, respectively. In our trial, with the maximum soil saturation period being only 3 days, it may be that oxidising conditions remained prevalent 
over the cooler winter period in all treatments. Consequent precipitation of $\mathrm{Mn}$ and Fe oxides under oxidising soil conditions would result in greater specific sorption of $\mathrm{Cd}[24,26]$, possibly explaining the overall decline in soil extractable Cd concentrations beyond day 42. Direct assessment of microbial respiration rate and/or redox potential was outside the scope of this project, being designed to follow irrigation/drainage methodology similar to that employed in previous research [30] to explore changes in metal phytoavailability with fluctuating soil moisture.

\subsection{Effect of Soil Type on Cd Phytoavailability and Uptake}

Despite soil total Cd concentration being 30\% greater in the Kereone soil than the Topehaehae soil ( 0.79 vs. $0.61 \mathrm{mg} \mathrm{kg}^{-1}$, respectively; Table 1 ), soil extractable $\mathrm{Cd}$ concentrations were around four times greater in the Topehaehae soil (Table 2). Correspondingly, tissue Cd concentrations were also greater (approximately double) for plantain grown in the Topehaehae soil than the Kereone soil (Table 2).

Although an inverse relationship between tissue $\mathrm{Cd}$ concentration and plant yield is frequently reported in the literature [44-46], this effect was only evident in the Kereone soil, resulting in equivalent plant $\mathrm{Cd}$ uptake between low-yielding flooded $\left(1.020 \mu \mathrm{g} \mathrm{Cd} \mathrm{pot}^{-1}\right)$ and high-yielding non-flooded $\left(1.001 \mu \mathrm{g} \mathrm{Cd}\right.$ pot $\left.^{-1}\right)$ irrigation regimes. In contrast, the greater extractable Cd concentrations of the Topehaehae soil sustained plant tissue $\mathrm{Cd}$ concentration irrespective of the differing plant growth rate under the two irrigation regimes, resulting in much greater plant $\mathrm{Cd}$ uptake for the high-yielding non-flooded treatment $\left(2.602 \mu \mathrm{g} \mathrm{Cd} \mathrm{pot}^{-1}\right)$ than the low-yielding flooded treatment $\left(0.880 \mu \mathrm{g} \mathrm{Cd} \mathrm{pot}{ }^{-1}\right)$ (Table 2). Our observation that an inverse relationship between plant tissue $\mathrm{Cd}$ concentration and plant yield only occurred at low Cd phytoavailability is consistent with the finding of Mortvedt et al. [45].

The differences in $\mathrm{Cd}$ phytoavailability between the two soil types can be explained by differences in soil characteristics. Although cation exchange capacity, $\mathrm{Mn}$ oxide, and $\mathrm{Fe}$ and $\mathrm{Al}$ amorphous oxide content have each been shown to be correlated with soil $\mathrm{Cd}$ desorption, soil total $\mathrm{Cd}, \mathrm{pH}$, and organic matter content are considered to be the dominant factors regulating $\mathrm{Cd}$ solubility and desorption [28]. Of these three factors, total $\mathrm{Cd}$ is positively correlated while soil $\mathrm{pH}$ and organic matter are negatively correlated $[9,28]$. The overriding effect of soil $\mathrm{pH}$ on metal phytoavailability is regularly cited in the literature-particularly for soils with high variable charge capacity, such as those in this study $[4,12,13]$. Notably, the $\mathrm{pH}$ of the Topehaehae soil was $0.7 \mathrm{pH}$ units lower than that of the Kereone soil at the outset of the trial. The greater $\mathrm{pH}$ of the Kereone soil, coupled with its greater organic matter content and predominance of variable charge clays (especially allophane and Mn oxides) is likely to explain the much lower extractable $\mathrm{Cd}$ concentrations of this soil type.

The importance of soil $\mathrm{pH}$ and organic matter content in regulating soil Cd solubility was demonstrated by Gray et al. [28], who developed an algorithm to predict soluble $\mathrm{Cd}$ concentrations based on these three factors, which accounted for $81 \%$ of the variation in soil solution $\mathrm{Cd}$ concentrations of $29 \mathrm{New}$ Zealand soils. This algorithm was used to predict Cd solubility for the soils in our study, using the soil $\mathrm{pH}$, carbon, and total $\mathrm{Cd}$ values in Table 1 (carbon being converted to soil organic matter using the Van Bremmelen factor of 1.724 [47]). Soil solution Cd concentrations were predicted to be almost three times greater for the Topehaehae soil than the Kereone soil. In relative terms, this is very similar to the approximate three-fold difference in mean soil extractable $\mathrm{Cd}$ concentrations measured for the Topehaehae and Kereone soils (i.e., $\sim 87 \mu \mathrm{g} \mathrm{kg}{ }^{-1}$ vs. $\sim 20 \mu \mathrm{g} \mathrm{kg}^{-1}$, respectively; Table 2), demonstrating the importance of soil $\mathrm{pH}$ and organic matter content in regulating the phytoavailability of soil total Cd.

\subsection{Implication of These Findings for Cd Management in Agricultural Soils}

The trend shown in our trial for increases in soil extractable Cd concentration with increases in soil moisture is a new and potentially important finding with regard to $\mathrm{Cd}$ management in agricultural soils. This observation suggests that after a period of drainage or soil drying, soil Cd phytoavailability is extremely sensitive to subsequent rainfall or irrigation inputs and indicates that $\mathrm{Cd}$ phytoavailability 
increases with increasing soil moisture prior to the point of saturation and the associated onset of reducing soil conditions.

This new knowledge may provide greater insight into appropriate soil $\mathrm{Cd}$ management strategies for minimising livestock dietary $\mathrm{Cd}$ exposure. For example, under typical New Zealand non-irrigated pastoral agriculture conditions, chicory and plantain crops are planted to provide quality feed when ryegrass-white clover-based pastures are compromised by hot, dry summer to early-autumn conditions [48]. As chicory and plantain have been shown to be 'Cd-accumulator' species [31] it is likely that their tissue $\mathrm{Cd}$ concentrations will be enriched following rainfall events that substantially increase soil moisture during the predominantly dry summer and autumn soil conditions. This effect has been observed in recent field trials investigating $\mathrm{Cd}$ accumulation in chicory (currently unpublished). Consistent across two contrasting soils, mean tissue $\mathrm{Cd}$ concentrations were significantly $(p<0.05)$ greater at the second harvest $\left(3.56-4.67 \mathrm{mg} \mathrm{kg}^{-1} \mathrm{DM}\right)$ relative to the first $\left(1.45-1.53 \mathrm{mg} \mathrm{kg}^{-1} \mathrm{DM}\right)$ and third (1.81-2.03 $\mathrm{mg} \mathrm{kg}^{-1} \mathrm{DM}$ ) harvests. Notably, a large rainfall event ( $23 \mathrm{~mm}$ rainfall within $24 \mathrm{~h}$ ) occurred during the second growth cycle that rewet the topsoil. In contrast, rainfall was infrequent and of low intensity during the first growth cycle, while only $1 \mathrm{~mm}$ of rainfall arrived during the entirety of the third growth cycle.

Practically, there is little ability to avoid grazing these crops following periods of increased soil moisture. Hence, where these Cd-sensitive crops are to be sown in Cd-enriched soil, management interventions should be explored to minimise potential increases in $\mathrm{Cd}$ phytoavailability that will be aligned with periods of increased soil moisture.

As soil $\mathrm{pH}$ is considered to be one of the single most important factors influencing $\mathrm{Cd}$ sorption-desorption behaviour and solubility $[4,5,10,13,28]$, managing soil $\mathrm{pH}$ at the upper end of the optimum range for these crops would be a logical starting point. However, the effect of increasing soil $\mathrm{pH}$ on $\mathrm{Cd}$ accumulation in plantain and chicory has yet to be quantified in field trials. Furthermore, although the sorption of $\mathrm{Cd}$ is known to increase with increasing soil $\mathrm{pH}$ with a concurrent shift towards less labile, specifically-sorbed Cd $[4,11,49]$, the assumption that this will reduce the size of the soil $\mathrm{Cd}$ fraction mobilised during periods of increased soil moisture needs to be proven. Further research in this area is warranted, as we do not yet fully understand the mechanisms behind the increases in Cd phytoavailability that were seen in our study that paralleled increases in soil moisture. Further to this, direct quantification of redox potential, soluble Mn/Fe concentrations, soil $\mathrm{Cd}$ fractionation, microbial respiration rate, and the influence of soil temperature is recommended for future research. This may help to explain the variation in soil extractable $\mathrm{Cd}$ concentrations observed in this research.

\section{Conclusions}

The results from this pot trial indicate that temporary fluctuations in soil moisture content can influence soil Cd phytoavailability, with increases in soil extractable $\mathrm{Cd}$ concentration paralleling increases in soil moisture content. However, soil saturation for short periods ( 3 days) did not appear to exert any influence on soil Cd phytoavailability, relative to irrigated but non-saturated soil conditions. The data from our trial suggest that plant tissue $\mathrm{Cd}$ concentrations are likely to be enriched in Cd-accumulator crops (such as chicory and plantain) during periods where soil moisture is abruptly increased following a period of drying. Our results also reinforce that soil $\mathrm{pH}$ and organic matter appear to be key factors regulating soil $\mathrm{Cd}$ phytoavailability, and need to be incorporated into $\mathrm{Cd}$ management frameworks where the objective is to manage risk of plant $\mathrm{Cd}$ accumulation.

Acknowledgments: We wish to acknowledge the Fertiliser Association of New Zealand (FANZ) for funding this research.

Author Contributions: A.D. Stafford and C.W.N. Anderson conceived and designed the experiments; A.D. Stafford performed the experiments; P.J. provided laboratory analytical support; A.D. Stafford analysed the data; A.D. Stafford wrote the paper with support from C.W.N. Anderson, P.J. and M.J. Hedley.

Conflicts of Interest: The authors declare no conflict of interest. 


\section{References}

1. Adriano, D.C. Trace Elements in the Terrestrial Environment; Springer: New York, NY, USA, 1986; 533p.

2. Smolders, E.; Mertens, J. Cadmium. In Heavy Metals in Soils: Trace Metals and Metalloids in Soils and Their Bioavailability; Alloway, B.J., Ed.; Springer: Dordrecht, The Netherlands, 2012; pp. 283-311.

3. Williams, C.H.; David, D.J. Some effects of the distribution of cadmium and phosphate in the root zone on the cadmium content of plants. Aust. J. Soil Res. 1977, 15, 59-68. [CrossRef]

4. Loganathan, P.; Vigneswaran, S.; Kandasamy, J.; Naidu, R. Cadmium Sorption and Desorption in Soils: A Review. Crit. Rev. Environ. Sci. Technol. 2012, 42, 489-533. [CrossRef]

5. Young, S.D. Chemistry of heavy metals and metalloids in soils. In Heavy Metals in Soils: Trace Metals and Metalloids in Soils and Their Bioavailability; Alloway, B.J., Ed.; Springer: Dordrecht, The Netherlands, 2012; pp. 51-95.

6. McLaughlin, M.J.; Tiller, K.G.; Naidu, R.; Stevens, D.P. Review: The behaviour and environmental impact of contaminants in fertilisers. Aust. J. Soil Res. 1996, 34, 1-54. [CrossRef]

7. Tiller, K.G.; Gerth, J.; Brummer, G. The relative affinities of Cd, Ni and $\mathrm{Zn}$ for different soil clay fractions and goethite. Geoderma 1984, 34, 17-35. [CrossRef]

8. McBride, M.B. Reactions controlling heavy metal solubility in soils. Adv. Soil Sci. 1989, 10, 1-56.

9. McBride, M.; Sauve, S.; Hendershot, W. Solubility control of $\mathrm{Cu}, \mathrm{Zn}, \mathrm{Cd}$ and $\mathrm{Pb}$ in contaminated soils. Eur. J. Soil Sci. 1997, 48, 337-346. [CrossRef]

10. Christensen, T.H.; Haung, P.M. Solid phase cadmium and the reactions of aqueous cadmium with soil surfaces. In Cadmium in Soils and Plants; McLaughlin, M.J., Singh, B.R., Eds.; Kluwer Academic Publishers: Dordrecht, The Netherlands, 1999; pp. 65-96.

11. Naidu, R.; Bolan, N.S.; Kookana, R.S.; Tiller, K.G. Ionic-strength and pH effects on the sorption of cadmium and the surface charge of soils. Eur. J. Soil Sci. 1994, 45, 419-429. [CrossRef]

12. Naidu, R.; Kookana, R.S.; Sumner, M.E.; Harter, R.D.; Tiller, K.G. Cadmium sorption and transport in variable charge soils: A review. J. Environ. Qual. 1997, 26, 602-617. [CrossRef]

13. Bolan, N.S.; Naidu, R.; Syers, J.K.; Tillman, R.W. Surface charge and solute interactions in soils. Adv. Agron. 1999, 67, 88-141.

14. Iu, K.L.; Pulford, I.D.; Duncan, H.J. Influence of waterlogging and lime or organic matter additions on the distribution of trace metals in an acid soil-I. Manganese and iron. Plant Soil 1981, 59, 317-326. [CrossRef]

15. Hernandez-Soriano, M.C.; Jimenez-Lopez, J.C. Effects of soil water content and organic matter addition on the speciation and bioavailability of heavy metals. Sci. Total Environ. 2012, 423, 55-61. [CrossRef] [PubMed]

16. Charlatchka, R.; Cambier, P. Influence of reducing conditions on solubility of trace metals in contaminated soils. Water Air Soil Pollut. 2000, 118, 143-167. [CrossRef]

17. Atta, S.K.; Mohammed, S.A.; Van Cleemput, O.; Zayed, A. Transformations of iron and manganese under controlled E(h), E(h)-pH conditions and addition of organic matter. Soil Technol. 1996, 9, 223-237. [CrossRef]

18. Kashem, M.A.; Singh, B.R. Metal availability in contaminated soils: I. Effects of flooding and organic matter on changes in Eh, pH and solubility of Cd, Ni and Zn. Nutr. Cycl. Agroecosyst. 2001, 61, 247-255.

19. Zheng, S.; Zheng, X.; Chen, C. Transformation of metal speciation in purple soil as affected by waterlogging. Int. J. Environ. Sci. Technol. 2013, 10, 351-358. [CrossRef]

20. Zhang, C.; Ge, Y.; Yao, H.; Chen, X.; Hu, M. Iron oxidation-reduction and its impacts on cadmium bioavailability in paddy soils: A review. Front. Environ. Sci. Eng. 2012, 6, 509-517. [CrossRef]

21. De Livera, J.; McLaughlin, M.J.; Hettiarachchi, G.M.; Kirby, J.K.; Beak, D.G. Cadmium solubility in paddy soils: Effects of soil oxidation, metal sulfides and competitive ions. Sci. Total Environ. 2011, 409, 1489-1497. [CrossRef] [PubMed]

22. McLaren, R.G.; Cameron, K.C. Soil Science: Sustainable Production and Environmental Protection, 2nd ed.; Oxford University Press: Auckland, New Zealand, 1996; p. 304.

23. Rumball, P.J. Pasture Plant, Water-Table Interactions on Manawatu Sandy Country. In Proceedings of the New Zealand Grassland Association 39, Palmerston North, New Zealand, 1977; Available online: https: / / www.grassland.org.nz/publications/nzgrassland_publication_1394.pdf (accessed on 9 February 2018).

24. Hindersmann, I.; Mansfeldt, T. Trace element solubility in a multimetal-contaminated soil as affected by redox conditions. Water Air Soil Pollut. 2014, 225, 1-20. [CrossRef] 
25. Cornu, S.; Cattle, J.A.; Samouelian, A.; Laveuf, C.; Guilherme, L.R.G.; Alberic, P. Impact of redox cycles on manganese, iron, cobalt, and lead in nodules. Soil Sci. Soc. Am. J. 2009, 73, 1231-1241. [CrossRef]

26. Backes, C.A.; McLaren, R.G.; Rate, A.W.; Swift, R.S. Kinetics of cadmium and cobalt desorption from iron and manganese oxides. Soil Sci. Soc. Am. J. 1995, 59, 778-785. [CrossRef]

27. Kim, N.D.; Fergusson, J.E. Adsorption of cadmium by an aquent New Zealand soil and its components. Aust. J. Soil Res. 1992, 30, 159-167. [CrossRef]

28. Gray, C.W.; McLaren, R.G.; Roberts, A.H.C.; Condron, L.M. Solubility, sorption and desorption of native and added cadmium in relation to properties of soils in New Zealand. Eur. J. Soil Sci. 1999, 50, 127-137. [CrossRef]

29. Ponnamperuma, F.N. The chemistry of submerged soils. In Advances in Agronomy; Academic Press: Cambridge, MA, USA, 1972; Volume 24, pp. 29-96.

30. Bhatti, S.M.; Anderson, C.W.N.; Stewart, R.B.; Robinson, B.H. Risk assessment of vegetables irrigated with arsenic-contaminated water. Environ. Sci. Process. Impacts 2013, 15, 1866-1875. [CrossRef] [PubMed]

31. Stafford, A.D.; Anderson, C.W.N.; Hedley, M.J.; McDowell, R.W. Cadmium accumulation by forage species used in New Zealand livestock grazing systems. Geoderma Reg. 2016, 7, 11-18. [CrossRef]

32. Powell, A.M.; Kemp, P.D.; Jaya, I.K.D.; Osborne, M.A. Establishment, Growth and Development of Plantain and Chicory under Grazing. In Proceedings of the New Zealand Grassland Association 69, Wairakei, New Zealand, 2007; Available online: https:/ / www.grassland.org.nz/publications/nzgrassland_ publication_144.pdf (accessed on 9 December 2017).

33. Li, Z.; McLaren, R.G.; Metherell, A.K. Cobalt and manganese relationships in New Zealand soils. N. Z. J. Agric. Res. 2001, 44, 191-200. [CrossRef]

34. Jeyakumar, P.; Loganathan, P.; Anderson, C.N.; Sivakumaran, S.; McLaren, R. Comparative tolerance of Pinus radiata and microbial activity to copper and zinc in a soil treated with metal-amended biosolids. Environ. Sci. Pollut. Res. 2014, 21, 3254-3263. [CrossRef] [PubMed]

35. Tukey, J.W. Exploratory Data Analysis; Addison-Wesley: Reading, PA, USA, 1977; 688p.

36. Gotoh, S.; Patrick, W.H. Transformations of manganese in a waterlogged soil as affected by redox potential and pH. Soil Sci. Soc. Am. J. 1972, 36, 738-742. [CrossRef]

37. DeLaune, R.D.; Reddy, K.R. Redox Potential. In Encyclopedia of Soils in the Environment; Hillel, D., Ed.; Academic Press: Amsterdam, The Netherlands, 2005; pp. 366-371.

38. Narteh, L.T.; Sahrawat, K.L. Influence of flooding on electrochemical and chemical properties of West African soils. Geoderma 1999, 87, 179-207. [CrossRef]

39. Gotoh, S.; Patrick, W.H. Transformations of iron in a waterlogged soil as influenced by redox potential and pH. Soil Sci. Soc. Am. J. 1974, 38, 66-71. [CrossRef]

40. Cornu, J.Y.; Denaix, L.; Schneider, A.; Pellerin, S. Temporal evolution of redox processes and free Cd dynamics in a metal-contaminated soil after rewetting. Chemosphere 2007, 70, 306-314. [CrossRef] [PubMed]

41. Gray, C.W.; McLaren, R.G.; Roberts, A.H.C.; Condron, L.M. Fractionation of soil cadmium from some New Zealand soils. Commun. Soil Sci. Plant Anal. 2000, 31, 1261-1273. [CrossRef]

42. Yamane, I.; Sato, K. Effect of temperature on the decomposition of organic substances in flooded soil. Soil Sci. Plant Nutr. 1967, 13, 94-100. [CrossRef]

43. Lovley, D.R. Microbial reduction of iron, manganese, and other metals. Adv. Agron. 1995, 54, $175-231$.

44. Loganathan, P.; Hedley, M.J.; Gregg, P.E.H.; Currie, L.D. Effect of phosphate fertiliser type on the accumulation and plant availability of cadmium in grassland soils. Nutr. Cycl. Agroecosyst. 1997, 47, 169-178. [CrossRef]

45. Mortvedt, J.J.; Mays, D.A.; Osborn, G. Uptake by wheat of cadmium and other heavy metal contaminants in phosphate fertilizers. J. Environ. Qual. 1981, 10, 193-197. [CrossRef]

46. Roberts, A.H.C.; Longhurst, R.D. Cadmium cycling in sheep-grazed hill-country pastures. N. Z. J. Agric. Res. 2002, 45, 103-112. [CrossRef]

47. Tan, K.H. Soil Sampling, Preparation, and Analysis, 2nd ed.; Taylor \& Francis: Boca Raton, FL, USA, 2005; 672p.

48. Somasiri, S.C.; Kenyon, P.R.; Kemp, P.D.; Morel, P.C.H.; Morris, S.T. Growth performance and carcass characteristics of lambs grazing forage mixes inclusive of plantain (Plantago lanceolata L.) and chicory (Cichorium intybus L.). Small Rumin. Res. 2015, 127, 20-27. [CrossRef] 
49. Bolan, N.S.; Adriano, D.C.; Mani, P.A.; Duraisamy, A. Immobilization and phytoavailability of cadmium in variable charge soils. II. Effect of lime addition. Plant Soil 2003, 251, 187-198.

(C) 2018 by the authors. Licensee MDPI, Basel, Switzerland. This article is an open access article distributed under the terms and conditions of the Creative Commons Attribution (CC BY) license (http:/ / creativecommons.org/licenses/by/4.0/). 